\title{
15. \\ RENESANSNI SUJET \\ DOSITEJA OBRADOVIĆA U „JEDNOM \\ POGLEDU NA LIČNOST DOSITEJEVU“ \\ VLADANA DESNICE ${ }^{1}$
}

\section{Jelena Đ. Marićević}

UDK: 821.163.42-4Desnica, V.:821.163.41Obradovi, D.

Pregledni članak

Sažetak: Rad obuhvata prevashodno analizu eseja "Jedan pogled na ličnost Dositejevu“, s uvodnim osvrtom na poredbene veze između Dositeja Obradovića, te domaćih i stranih kulturnih i književnih delatnika. Fokus rada je na mogućnosti sagledavanja lika ličnosti srpskog prosvetitelja, tj. slikarskim jezikom govoreći - sujeta, onoga što je slikar, a u ovom slučaju - pisac i esejista, predstavio. Dositejev sujet bio bi, stoga, nalik predstavi mladića sa Đorđonove slike Oluja (1508.), na osnovu načina na koji ga Desnica portretiše, prevashodno potcrtavajući njegov pesnički potencijal. U prilog tezi da je Vladan Desnica mogao imati u vidu slikarski predložak za Dositejevu ličnost jeste njegov prevod knjige Lionela Venturija Od Đota do Šagala iz 1952. godine, jer Venturi ne samo da definiše sujet, već o Đorđoneu ima još dve knjige od kojih je Desnica barem jednu mogao imati u čitalačkom iskustvu kada piše esej o srpskom prosvetitelju, iako nemamo eksplicitan dokaz da ih je čitao ranije: Đordone i dorđonizam (1913.), te Đordone (1954.). Sam Venturi vidi upravo umetnikovu ličnost kao zakonodavca umetnosti, što je moglo da utiče na Desnicu. U konačnici, važnost ovog zapažanja sugeriše nam da Dositejeva ličnost za Desnicu znači jedan od simbola za proleće poezije, njen nagoveštaj, pa i renesansu, tj. preporod koji će nastupiti sa romantizmom.

Ključne reči: esej, poezija/poetsko, slikarstvo, prosvetiteljstvo, renesansa, estetika, imaginacija

Tedan pogled na ličnost Dositejevu“ svakako je jedan od najvǎnih esejističkih tekstova Vladana Desnice, koji je neretko do sada zavređivao pažnju kritičara, književnih 99 teoretičara i istoričara. Slavko Gordić, primera radi, razmatrao je teme i interesovanja Vladana Desnice, te ono što spaja književne i kulturne srodnike Dositeja Obradovića, one sa kojim ga Desnica poredi, ali i ukazao da „nismo načisto da li je Dositej paradigmatičan predstavnik svoje epohe, ili je samo 'fazoniran' po njenom modelu“2. Povrh svega, skrenuo

jelena.maricevic@ff.uns.ac.rs

2 Славко ГорАит, „Владан Аесница: критичко-есејистичка слика наслеђа“, Профили и ситуације. O српској къижевној мисли 20. века, БеограА 2004., 9-12. 
je pažnju i na esej Dušana Marinkovića „Igre Vladana Desnice“, koji govori o Desničinom pokušaju skice filmskog scenarija o Dositeju, pod naslovom Vječiti putnik³. Nikolina Konjević, pak, smatra da ovim esejem Desnica „razotkriva podvojenost i složenost ljudskog bića, a prikazuje kakav je čovjek u rasponu svojih širokih mogućnosti, od dobra do zla“"

Neretko je ukazivano i na veze između srpskog prosvetitelja sa Jurjem Križanićem, Pavlom Vitezovićem, Solarićem, Trlajićem, Zorićem, Vujićem, Zelićem, Simom Milutinovićem, od domaćih kulturnih delatnika, a od stranih sa Pikom de la Mirandolom, Benvenutom Čelinijem, Tomazom Kampanelom, Siranom de Beržerakom. Jurja Križanića, Simeona Zorića i Gerasima Zelića povezuje prostor današnje Belorusije, ${ }^{6}$ tj. Šklova, u kojem su živeli i delali. Dositej Obradović boravio je od kraja 1787. do polovine 1788. na Zorićevom imanju. Križanić je promovisao ideju sveslovenstva kao jezičke i etničke celine, ali i ideju crkvene unije kroz jedinstvo sa Rusijom, Zorić 1778. osniva „Šklovsku plemićku školu“ (Dositej je zaslužan za osnivanje Velike škole), a Zelić se rano zamonašio i otišao u svet, baš kao i Dositej. Sovjete zdravago razuma Dositej je posvetio upravo Zoriću, a Grigoriju Trlajiću pesmu u kojoj mu poručuje: Pevaj pesmu i opevaj sas darovi musu / Po najluščem, jedinstvenom, Terlajiča vkusư . Što se tiče relacije Solarić - Dositej, može se govoriti o obostranom interesovanju za obrazovanje, a Vitezović je radio na pravopisu i štamparskom poslu, dok je i Dositeju važan cilj bio obrazovanje naroda, ali je njegov jezik postao specifičan dositejevski tip jezika koji ide ka vernakularizaciji. Najposle, Joakima Vujića i Dositeja povezuje neprestana želja za putovanjima, tj. stranstvovanjem. ${ }^{8}$

Poređenje Dositeja sa Njegošem poređenje je po suprotnosti; ono što je Njegoš za portretisanje Dositeja, to bi mogao da bude Matavulj za samog Desnicu. Matavulj je bio učitelj u okolini Zadra, a Desnica mu je zamerio da iako je „imao oštro oko i oštar, gotovo naturalistički prilaz stvarnom životu - ukoliko se u svom radu dotakao tog zadarskog kraja, zadržao se uglavnom na folklornom dekoru i na kasnim odjecima narodne epike“, a ,skoro niko nije obratio ozbiljniju pažnju na život čovjeka i na njegova životna pitanja “9, što Desnica upravo čini. Ova poređenja po suprotnosti, čini se da su i kontrastni valeri između prosvetiteljstva i romantizma, tj. realizma i modernizma, sugerisani na osnovu ličnosti umetnika, na kojoj Desnica insistira: „meni se čini da se kod nas previše pažnje posvećuje pitanju škole, pravca, manira, programskog opredjeljenja, a manje samoj 'ličnosti’ pisca“"10.

Ličnost, ali ujedno i lik Dositejev Vladan Desnica portretiše, dakle, prema sličnosti i suprotnosti, prema domaćim delatnicima i umetnicima, te prema stranim. Od stranih, redom od najstarijeg do najmlađeg, njegova ličnost osenčena je Pikom dela Mirandolom (1463.

\footnotetext{
Hcmo, 24.

Николина Коњевит, „„Поглед’ ВАадана Аеснице на мичност Аоситејеву“, Поља, 52/2007., 6р. 443, 101.

5 Vladan Desnica, „Jedan pogled na ličnost Dositejevu“, Eseji, kritike, pogledi, Sabrana dela: knj. 4 (red. Stanko Korać), Zagreb 1975., 9.

6 убивоје Церовић, Срби у Белорусији, БеограА - Нови СаА 1997.

7 Аоситеј Оврадовић, Песме. Писма. Аокументи, Сабрана дела: књ. 6 (прир. Мирјана А. Стефановић), БеограА 2008., 16.

8 Према: Јелена МАрићевић, „Српско и хрватско књижевно наслеђе у есејима ВАадана Аеснице“, Траг, 8/2012., књ. 8, св. 29, 99-111.

9 V. Desnica, „O jednom gradu i o jednoj knjizi“, Eseji, kritike, pogledi, 96.

10 Isti, „Razgovor na književnom petku“, Eseji, kritike, pogledi, 88.
} 
- 1494.), Benvenutom Čelinijem (1500. - 1571.), Tomazom Kampanelom (1568. - 1639.) i Siranom de Beržerakom (1619. - 1655.). Dakle, od trojice Italijana, predstavnika humanizma i renesanse, do francuskog dramskog pisca, Desnica ispisuje linije dodira: Mirandola se zalagao za filozofiju mira i verskog pomirenja, napisao je ključni tekst renesansnog humanizma „O ljudskom dostojanstvu“ i borio se protiv astrološkog proricanja, a Dositej protiv sujeverja. Čelinijev Život „otvara nam pristup u svet renesanse bolje nego mnoge akademske studije i približava nam taj veliki period do te mere da nam postaje familijaran i blizak" "11, a Dositejev Život i priključenija ključno je delo srpskog prosvetiteljstva. Dositejeve utopističke težnje, poredive su sa Kampanelinim Gradom Sunca, a sa Beržerakom ga možda takođe spaja direktan upliv biografskog u ono što piše.

Dositej je, prema tome, ličnost humanizma i renesanse, ujedno i prosvetiteljstva, možda unekoliko nalik Johanu Vinkelmanu, koji jeste živeo u 18. veku, ali je po duhu pripadao ranijem vremenu. „Svojim oduševljenjem za stvari intelekta i mašte radi njih samih, svojim jelinizmom, svojom doživotnom borbom da dostigne grčki duh on je srodan humanistima ranijih vremena. On je poslednji plod renesanse i na upečatljiv način objašnjava njen motiv i stremljenja “. ${ }^{12}$ Dositej kao putnik, znatiželjnik, sa težnjom da sazna, otkrije, dosegne, jeste renesansna ličnost. Međutim, Desnica ne bi bio pisac i kada esejizira, ne bi bio kompletan Umetnik da Dositeja nije u izvesnom smislu i naslikao. U intervjuu „Razgovor s Vladanom Desnicom o umjetničkom stvaranju“, odgovarajući na Milovićevo pitanje da li koristi bakroreze, slike i slične stvari za pesničko stvaranje, kao Klajst ili kao Dučić ili kao Tomas Man, odgovara da misli kako

ni Dučić ni Klajst ne rade svjesno, ali da se u nama kuhaju i previru i ispremeštavaju sve te impresije to je jasno, pa da često čak i ne znamo je li jedan štimung, jedno nastrojenje, jedan ugođaj, jedan pejzaž (...) doživljaj slike je isto što i doživljaj kao i doživljaj gole realnosti, pa jasno da i to sudjeluje u našem stvaranju. ${ }^{13}$

Mišljenja smo da je pišući o Dositeju Desnica možda nesvesno, a možda jednim delom i svesno, portretisao srpskog prosvetitelja prema poznatoj Đorđoneovoj slici Oluja.

$\mathrm{Na}$ to, naime, upućuju pojedini delovi teksta koji se odnose na njegovu prirodu, osećajnost, njegov odnos prema ženama i deci, te na insistiranju o njegovoj poetski nastrojenoj duši:

1. Dositej nije nimalo vulkaničan, nimalo strastven. U njegovom nemirnom duhu ima nečeg elegičnog i čeznutljivog. Njega ne tjera u svijet jedan eruptivni poriv; njega vuče neka neodređena nostalgija ${ }^{14}$.

11 Eros Sekvi, „Predgovor“, u: Benvenuto Čelini, Moj život (prev. Jugana Stojanović), Beograd 1963., 14. Eros Sekvi i Vladan Desnica, inače, vodili su prepisku i sarađivali su na planu književnosti i prevođenja. V.: Жеько Ђурит, „Вцадан Аесница и Ерос Секви - преписка и око ње“, Зборник Матице српске за къижевност и језик, 57/2009., св. 2, 399-423.

12 Волтер Пејтер, Ренесанса. Есеји о уметности и песнищтву (прев. Живојин Симић), БеограА $1965 ., 12$.

13 V. Desnica, „Razgovor s Vladanom Desnicom o umjetničkom stvaranju“, Eseji, kritike, pogledi, 226.

14 Isti, „Jedan pogled na ličnost Dositejevu“, Eseji, kritike, pogledi, 10. 


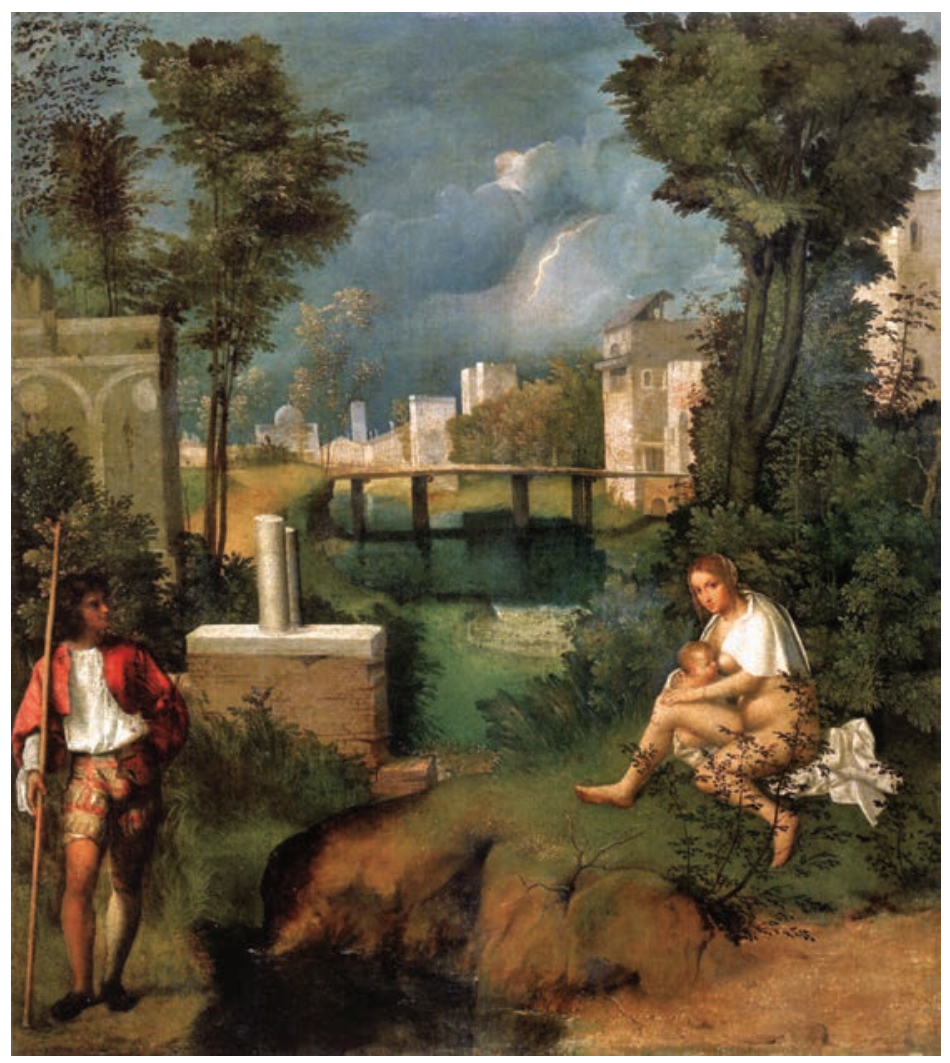

Đorđone, Oluja

2. Dositej je izrazito pjesnička narav ${ }^{15}$.

3. Teško da bi se mogao naći u našoj književnosti drugi primjer takve nježnosti i finoće osjećaja, takve jednostavnosti i neposrednosti lirskog izraza ${ }^{16}$.

4. Dositej je pjesnik intimne domaće idile i krotke porodične sreće. U svom kultu familije, on gleda ženu kao stub porodice, kao druga u životu, kao meki, nježni ton u obiteljskim brigama, kao element sklada i ljepote u zajednici. U njemu predodžba žene pobuđuje misao na odnos između majke i djeteta prije nego na odnos između čovjeka i žene ${ }^{17}$.

5. Da je Dositej živio nešto kasnije, kad je model vremena bila poetski nastrojena duša, on bi bio naš najvedriji pjesnik čiste, svijetle radosti života, pjesnik bogodane, vječno mlade naivnosti duha, pjesnik svježine, pjesnik sreće, pjesnik dobrote i ljubavi među ljudima. U njemu bi kao ni u kome drugome kod nas vladao široki, duboko humani osjećaj koji obujmljuje čitavo čovečanstvo i ujedinjuje ga u veri u bolju budućnost i u konačnu pobjedu dobra na zemlji; u obmani da je čovjek u suštini dobar; u iluziji da će doći jedno doba savršene, sretne harmonije, u toj najsvetlijoj iluziji čovjekove duše $\mathrm{e}^{18}$.

Đorđoneova Oluja bila je omiljena Bajronova slika. Smatrao je da tema i simbolika ove slike svakom posmatraču omogućava da osmisli sopstvenu priču. Takođe, Oluja označava 
početak onoga što će postati važno novoj tradiciji u umetnosti, a to je stvaranje slikarskih pandana pesmama umesto pričama; otuda je možda elementarno važno Desničino insistiranje na Dositejevoj pesničkoj naravi. Dositejev pesnički opus, nije, razume se, velik, ali u njemu ima idile, bukoličkog, tj. pastoralnih elemenata i slika prirode. „Deskriptivna 'poezija prirode’ XVIII veka karakteristično je puna vizuelnih slika, a dominantni metaforički oblik - personifikacija - sam po sebi je slikovit“. ${ }^{19}$ „Poeziju prirode ${ }^{\text {“20 }}$ negovala je antika u vidu bukoličkih pesama, utoliko značajnih, što na elemenat pastirskog treba računati kada se govori i o Dositejevim pesmama, ali je i mladić na Đorđoneovoj slici pastir ili vojnik, smešten u jedan doduše poluidiličan pejzaž, s nostalgičnim pogledom na majku koja doji dete, a koja iako samo oskudno ogrnuta, gotovo naga, izgleda čedno i nevino, nema u njoj erotskog, već samo majčinskog; ima one lepote koju Dositej ceni - ima nežnosti, krotke porodične sreće, sklada i lepote u zajednici. Dositejeva ličnost sagledana je u liku mladića, pastira ili vojnika, koji samo s nežnošću gleda ženu i dete, on dodir ostvaruje poluprofilom, a deli ih potočić. Oluja u dnu slike, značila bi ono nadolazeće, tj. neodrživost Dositejevog optimizma i naivnosti u konkretnom životu; za vojnika - verovatno rat, narušavanje idile, napuštanje doma. Njega kao da u svet vuče ona neodoljiva nostalgija koju Desnica spominje kada govori o Dositeju.

Da je Desnica ovo mogao imati u vidu donekle sugeriše njegov prevod knjige Lionela Venturija Od Đota do Šagala, ${ }^{21}$ u kojoj je 4. poglavlje posvećeno „Otkriću prirode“ i otpočinje interpretacijom upravo Đorđoneove Oluje. Na sve to, još neke od poznatijih Venturijevih knjiga jesu bezmalo Đordone i dordonizam (1913.) i Đordone (1954. ${ }^{22}$, te nije neisključeno da je makar knjigu štampanu 1913. godine mogao imati u rukama, budući da je esej "Jedan pogled na ličnost Dositejevu“ objavio 1934. godine u Magazinu Sjeverne Dalmacije. Venturi za Đorđonea kaže da je postavio jedan novi cilj, zamišljao je svet na slobodniji način, slika kod njega dobija lirsku vrednost, rešio se problem efekta svetlosti i senke, i to ne

19 Rej Frejzer, „Poreklo termina 'slika'“, Pesnička slika (prir. Miroslav Šutić), Beograd 1978., 42.

20 „Priroda je isključiv predmet Dositejevih poetskih slika“, napisao je Jovan Deretić (Поетuка, Аоситеja Oбрадовића, Београд 1974., 162-163) kada je govorio o poetskim slikama u Sovjetima.

21 Venturijeva knjiga Od Giotta do Chagalla izašla je u Desničinom prevodu u izdanju Mladosti iz Zagreba 1952. i 1957. godine, i to samo četiri godine nakon italijanskog izdanja 1948. (prvobitno je knjiga objavljena na engleskom jeziku 1945. godine). Međutim, godine 2008. pojavila se Venturijeva knjiga Od Đota do Sagala, pod naslovom Kako razumeti sliku, a u navodnom prevodu Dolores Kalođera-Petrović. Nažalost, ustanovljeno je da je Dolores Kalođera-Petrović samo minimalno preradila prevod Vladana Desnice, uglavnom, izbacujući ijekavicu i menjajući poneki kroatizam rečju čiji smisao je u široj upotrebi. Primera radi:

„Venecijanski slikar Đorđone (Giorgione, 1480-1510), koji je umro veoma mlad, imao je jedan novi cilj. On je koncentrisao svoju pažnju na prirodu i shvatio ljudsko biće ne više kao centar svemira, već kao jedan od njegovih elemenata. I tako je on, kada je reč o slikarstvu, otkrio prirodu“ (Lionelo Venturi, Kako razumeti sliku. Od Đota do Šagala (prev. Dolores Kalođera-Petrović), Beograd 2008., 77).

„Venecijanski slikar Giorgione, koji je umro veoma mlad (1480.-1510.) imao je jedan novi cilj. On je usredotočio svoju pažnju na prirodu i shvatio ljudsko biće ne više kao centar svemira, već kao jedan od njegovih elemenata. I tako je on, u pogledu slikarstva, otkrio prirodu“ (L. Venturi, Od Giotta do Chagalla (prev. Vladan Desnica), Zagreb 1952., 80).

Desničin prevod Venturija, Dušan Bošković sagledao je u svetlu svedočanstva koje krši načela neformalne i podrazumevajuće represivnosti u jednom vremenu, budući da se članovi redakcije koja je objavila knjigu otvoreno ne slažu sa njenim idejnim postavkama. V. Dušan Bošković, „Manojlović, Šejka i Desnica o umetnosti“, Filozofija i društvo, 11/1997., 46.

22 Dragan Jeremić, „Predgovor“, u: Lionelo Venturi, Istorija umetničke kritike (prev. Vera Bakotić-Mijušković), Beograd 1963., XIII-XIV. 
neutralnim gradacijama, već intenzivnim bojama (po principu tona), i ljubeći drveće, reke, nebo, prožeo ih je humanitetom. ${ }^{23}$ Đorđoneov humanitet blizak je Dositejevom u pesmi s početnim stihom Sve što mene okružava: Sve što mene okružava, sve to sa mnom tuži: / Niti ptica ptici poje, nit se s drugom druži. / Odziv meni iz gorice s plačem odgovara, / Zefir mi se među lišćem na žalost pretvara. I I potoci s ladnom vodom svi sa mnom uzdišu / Prolivajte, oči moje, gorki'suza kišu $u^{24}$. Dositejev lirski subjekat deo je prirode, sa njom otvoreno komunicira i deli empatično svoje emocije. To je, kako Desnica napominje, onaj Dositejev „duboko humani osjećaj koji obujmljuje čitavo čovečanstvo i ujedinjuje ${ }^{\text {"25, }}$, to je možda i nešto slikarski renesansno, a književno gledano, predromantičarsko u Dositeja.

U eseju „Pramaljeće jedne poezije“, Desnica kaže da se dolce stil nuovo

pojavljuje na izlasku iz srednjeg vijeka i u praskozorje jednog novog doba. Jednako kao i nova strujanja u likovnim umjetnostima u to doba, on djeluje kao nastup proljeća poslije duge zime (...) ono lirsko „pramaljeće“ (...) to proljeće, koje se vječito navraća, taj vječno mladi momenat duha (...) Jedno takvo buđenje novih lirskih sokova, osvježeno i pomlađeno pučkim elementima, nalazimo kod nas, na primjer u Branku Radičeviću ${ }^{26}$.

Pišući esej „Romantično proleće Dositeja Obradovića“, Todor Manojlović takođe spominje Dantea, divnu procvast italijanske poezije, slatki novi stil, ali i Dositeja kao čoveka, pisca, pesnika, njegovu detinjski vedru, usrdnu i poletnu, boemsku osećajnost, koja je prisna, naravno, i u njegovoj autobiografiji, a autobiografije su - rekao je Gete - smesa poezije i istine. ${ }^{27} \mathrm{U}$ eseju „Ličnost i prosede“, Desnica ukazuje na „autentičnost i 'istinitost' (podvlačim tu riječ) umjetnikove ličnosti (...) Pod tim mislim na ono što se obično kaže: da li čovjek piscu 'vjeruje' ili 'ne vjeruje ${ }^{\text {'“28. }}$.

Kada je reč o istinitosti jedne ličnosti, makar ona imala lik ili sujet (ono što je slikar predstavio) sa slike, jer to ne umanjuje njenu istinitost, valjalo bi možda i ukazati na razmatranja Dragana Jeremića o Vladanu Desnici u knjizi simptomatičnog naslova Prsti nevernog Tome. Ne samo da Jeremića i Desnicu jednim delom povezuje interesovanje za Lionela Venturija - Desnica ga prevodi, Jeremić piše predgovor za knjigu Istorija umetničke kriti$k e$, upravo naglašavajući Venturijevo viđenje umetnikove ličnosti kao zakonodavca umetnosti ${ }^{29}$, već Jeremić u nekoliko ključnih poteza, tj. rečenica, može se reći, ispisuje poentu Desničine estetike. On piše o njegovim pitoresknim detaljima i jezičkim bravurama koje vode ka spajanju humanosti i artizma ${ }^{30}$, a zatim podvlači Desničinu ideju da se izrazima poetsko i poezija naprosto označava svaka prava estetska umetnička vrednost, pa i sasvim

\footnotetext{
23 L. Venturi, Od Giotta do Chagalla, 80-84.

24 А. Оврадовић, Собраније разних наравоучителних вештеј (Мезимаи), Сабрана дела: књ. 4 (прир. Мирјана А. Стефановић), БеограА 2008., 166.

25 V. Desnica, „Jedan pogled na ličnost Dositejevu“, 24.

26 Isti, „Pramaljeće jedne poezije“, Eseji, kritike, pogledi, 139, 142.

27 Тодор Манојиовић, „Романтично пролеће Аоситеја Обрадовића“, Аетопис Матице срnске, 137/1961., књ. 387, св. $6,508,513,515$.

28 V. Desnica, „Ličnost i prosede“, Eseji, kritike, pogledi, 115.

29 D. Jeremić, „Predgovor“, XVII.

30 Араган Јеремић, „ВАадан Аесница“, Прсти неверног Томе, Београд 1965., 153.
} 
nepoetični produkti (99\% teatra nije poezija, a antipoetični Kafka, pa i misaoni Montenj, jesu poezija) ${ }^{31}$.

Mišljenja smo da je svesno ili nesvesno, ali svakako artificijelno, estetski istančano, Vladan Desnica gledajući na ličnost Dositejevu, u njoj video sav slikarski kapacitet zrele renesanse, proleća poezije kakvu bi pisao Dositej da je živeo kasnije. To je onaj sklad lirskog i idejnog, emotivnog i razumskog, stvaralačkog i iskustvenog, o čemu je pisao Jeremić, kao o neprolaznoj vrednosti intelektualne poezije ${ }^{32}$. Konačno, ako se proleće poezije sagleda $\mathrm{u}$ svetlu Desničine pesme Proljeća: S proljeća iskrsnu u nama / sva naša minula proljeća. / To su godovi duše. // Svako je od njih jedno novo mitarenje: / iz njega klisne biće / u novom perju / i uzlijeće k suncu / sa cijukom novim ${ }^{33}$, slutimo čar optimizma, buđenja, uzleta, preporoda koju nose i ovi stihovi i potencijal Dositeja kao pesnika.

To što, međutim, Dositej nije ostvaren kao pesnik, s obzirom na malen i estetski ne toliko vredan pesnički opus, on je u izvesnom smislu neostvaren umetnik, velika ličnost, ali možda ipak manji u stvaralačkom smislu. Eventualno bi mogao da se uporedi sa virtouzom, koga pominje i u kome se prepoznaje Ivan Galeb, koji naprosto ostaje neostvaren, zbog, ne doduše nesreće da unakazi ruku, već nesreće da bude rođen pre vremena u kome bi ostvario svoj pesnički potencijal:

Zacijelo je i on [doktor] čuo priču o tragediji virtouza koji je nesrećnim slučajem, ili nesmotrenošću, na veselom izletu, kad se najmanje mogao tome nadati, iznakazio ruku, i time se upropastio i onesposobio za dalju karijeru; i to uprav u času kad je već stajao na pragu slave - itd., itd. Obična slatka pričica, dobra za šiparice i za posljednje stranice sedmičnih ilustracija. I kadra čak, uz minimum spretnosti, da čovjeku donese kudikamo više slave nego što bi mu ikad mogla donijeti ona promašena karijera. ${ }^{34}$

Međutim, Dositeja ličnost spasava banalnosti „slatke pričice“, i po tome, on se bitno razlikuje od onesposobljenog virtouza, od Ivana Galeba najposle, koga možemo prepoznati u priči koja je idealna za sedmične ilustracije. Dositej je iskrslo proleće, tek cijuk, ali ne i poj, tek pogled pastira ili vojnika sa Đorđonove slike, ali ne i dodir, tek nagoveštaj. Ivan Galeb snagu i sjaj sopstvene ličnosti zadobija evociranjem svojih proljeća, sećanjem na uzlete, preporode duha, svoje male renesanse, na svaki novi god duše, svako novo mitarenje. Možda se zapravo radi o tome da ličnost pokreće proleće i proleće pokreće ličnost, čak i ako ličnost neće biti vrhunski umetnik, virtouz, genije. Dovoljan je potencijal, polet, proleće, duh ličnosti, lik koji se prepoznaje, da bi vreme i zrenje donelo vrhunskog virtouza ili genija. 


\section{$\cos$}

\section{Dositej Obradović as a Renaissance sujet in Vladan DESNiCA'S "A LOOK AT THE FIGURE of Dositej"}

The paper chiefly delivers an analysis of the essay "A look at the figure of Dositej” ("Jedan pogled na ličnost Dositejevu"), with an introductory overview of the comparative links between Dositej Obradović and different cultural and literary figures of national and international significance. One of the issues the paper focuses on is the possibility of analyzing the figure of that Serbian enlightener, or what is referred to in art as the sujet - that which the artist (or in this case, the essay writer) chose to represent. The sujet of Dositej as Desnica portrays him, focusing on his potential as a poet, is not unlike the image of the young man from Giorgione's painting The Tempest (1508). The fact that Desnica translated Lionello Venturi's 1952 book Da Giotto a Chagall (From Giotto to Chagall) supports the assumption that he drew inspiration for his depiction of Dositej from the painting. Venturi defined the term sujet in that book, and wrote another two books on Giorgione: Giorgione e il Giorgionismo (Giorgione and Giorgionism) (1913) and Giorgione (1954). At least one of those books (the 1913 one) could easily have been read by Desnica before he embarked on the essay on the Serbian enlightener. Venturi himself believed that it is the artist's personality that should determine the laws of art, which could have shaped Desnica's own views. In the end, the importance of this observation suggests that the figure of Dositej functions $s$ as a symbol for a kind of spring of poetry, a foretelling of rebirth, a renaissance of poetry to be brought about by Romanticism. However, the figure of Dositej, interpreted in light of Giorgione's Tempest, is marred by a sort of melancholy, suggesting that as a poet and an artist Dositej is, in Bernhard's terms, a loser. His poetic potential is but a chirp, not a fully developed song, a flail of wings not yet developed into flight. Dositej's output foretells romanticism, although it is optimistic, positive, upbeat and childlike in nature, even naive, and as such, untenable in the face of turmoil, or a tempest. In this sense, he is reminiscent of the hero of the novel Proljeca Ivana Galeba (The Springs of Ivan Galeb), yet fundamentally different. Desnica uses the term springs in the poem of the same title Proljeća ('Springs'), the novel (The Springs of Ivan Galeb) and his essays ("A look at the person of Dositej", "The spring of a poetry"): what is more, all these springs permeate each other and can only be interpreted in all their complexity through a comprehensive renaissance lens.

Key words: essay, poetry/the poetic, painting, the Enlightenment, the Renaissance, aesthetics, imagination

\section{$\cos$}

\section{Izvori}

Vladan Desnica, „Jedan pogled na ličnost Dositejevu“, Eseji, kritike, pogledi, Sabrana dela: knj. 4 (red. Stanko Korać), Zagreb 1975., 9-24.

Vladan DesnicA, ,Jedan zakašnjeli prilog diskusiji o 'tipičnome'. Razgovor na 'Književnom petku'“, Eseji, kritike, pogledi, Sabrana dela: knj. 4 (red. Stanko Korać), Zagreb 1975., 71-91.

Vladan Desnica, „Ličnost i prosede“, Eseji, kritike, pogledi, Sabrana dela: knj. 4 (red. Stanko Korać), Zagreb 1975., 113-116. 
Vladan Desnica, „O jednom gradu i o jednoj knjizi“, Eseji, kritike, pogledi, Sabrana dela: knj. 4 (red. Stanko Korać), Zagreb 1975., 92-104.

Vladan Desnica, „Pramaljeće jedne poezije“, Eseji, kritike, pogledi, Sabrana dela: knj. 4 (red. Stanko Korać), Zagreb 1975., 137-144.

ВАадан АЕсницА, Прољећа Ивана Галеба (прир. Радивоје Микић), Београд 2005.

Vladan Desnica, „Razgovor s Vladanom Desnicom o umjetničkom stvaranju“, Eseji, kritike, pogledi, Sabrana dela: knj. 4 (red. Stanko Korać), Zagreb 1975., 214-245.

Vladan Desnica, Slijepac na žalu (pogovor: Vladimir Rismondo), Zagreb 1956.

Аоситеј Оьрадовит, Песме. Писма. Аокументи, Сабрана дела: књ. 6 (прир. Мирјана А. Стефановић), БеограА 2008.

Аоситеј Оврадовит, Собраније разних наравоучителних вештеј (Мезимау), Сабрана дела: књ. 4 (прир. Мирјана А. Стефановић), Београд 2008.

\section{Literatura}

Dušan BošKović, „Manojlović, Šejka i Desnica o umetnosti“, Filozofija i društvo, 11/1997., 43-81. Һубивоје Церовит, Срби у Белорусији, БеограА - Нови СаА 1997.

Јован АЕРетић, Поетика Аоситеја Обрадовића, БеограА 1974.

Жемко Ђурић, „ВАадан Аесница и Ерос Секви - преписка и око ње“, Зборник Матище српске за книжевност и језик, 57/2009., св. 2, 399-423.

Rej Frejzer, „Poreklo termina 'slika'“, Pesnička slika (prir. Miroslav Šutić), Beograd 1978., 39-48.

Славко ГорАит, „Владан Аесница: критичко-есејистичка слика наслеђа“, Профили и ситуације. О српској књижевној мисли 20. века, БеограА 2004., 7-24.

Dragan Jeremić, „Predgovor“, u: Lionelo VENTURI, Istorija umetničke kritike (prev. Vera BakotićMijušković), Beograd 1963., XI-XXVIII.

Араган Јеремић, „ВАадан Аесница“, Прсти неверног Томе, Београд 1965., 152-176.

Николина КоњЕвић, „„ПоглеА’ ВцаАана Аеснице на мичност Аоситејеву“, Поља, 52/2007., бр. 443, 93-101.

Јемена МАРићевић, „Српско и хрватско књижевно наслеђе у есејима ВАадана Аеснице“, Траг, 8/2012., књ. 8, св. 29, 99-111.

Тодор МАнојмовић, „Романтично пролеће Аоситеја Обрадовића“, Аетопис Матице сриске, 137/1961., књ. 387, св. 6, 499-523.

Волтер Пејтер, Ренесанса. Eсеји о уметности и песништву (прев. Живојин Симић), БеограА 1965.

Eros Sekvi, „Predgovor“, u: Benvenuto ČElini, Moj život (prev. Jugana Stojanović), Beograd 1963., 7-14.

Lionelo Venturi, Kako razumeti sliku. Od Đota do Šagala (prev. Dolores Kalođera-Petrović), Beo$\operatorname{grad} 2008$.

Lionelo Venturi, Od Giotta do Chagalla (prev. Vladan Desnica), Zagreb 1952. 